\title{
ENABLING HIGH VALUE CARE WITH A POINT OF CARE SOLUTION: THE AUSTRALIAN EXPERIENCE
}

\author{
Nilmini Wickramasinghe \\ Epworth HealthCare \& Deakin University, Australia \\ nilmini.work@gmail.com
}

\begin{abstract}
Adopting patient-centric technology solutions is considered a critical enabler to enhance superior, high value healthcare delivery. Evidence from the literature underscores the simultaneous benefits of such an approach for enhancing the quality of care, increasing value and reducing associated costs. This study contributes to the current void in the literature by providing data from an implementation of a patient-centric solution that serves to deliver and support value based-care. Specifically, the presented study highlights how a point of care system can deliver high value patient-centric care across a healthcare group in Australia. The results from this qualitative study show that the examined point of care system supports patient-centric care by facilitating a high level of patient engagement and supporting key safety and quality care outcomes, as well as building a cultural shift towards patient-centric care as part of standard practice. The study has far reaching implications for both theory and practice.
\end{abstract}

\section{Introduction}

Healthcare is transitioning from a focus on volume to one on value [10]. This value agenda is dependent on outcomes, engagement, quality, expenditures and access; parameters important to all major Healthcare stakeholders [15]. Technology implementations from electronic medical and health records to devices that provide for the remote monitoring of physiologic parameters facilitate significant value generation resulting in improved patient-centred care [16]. To date few studies have focussed on systematically addressing how technology solutions might impact and enable a value agenda to ensue. This study addresses this void by examining in depth the benefits of a Point of Care solution.
Over the past decade, the healthcare industry has started to invest significantly in various health IS/IT to enhance care outcomes and control the escalating costs. These two aspects have been major criteria to be addressed by health informatics researchers [8]. Today, there exist various studies that investigate the impact of IS/IT on specific aspects of healthcare delivery such as patient outcomes, e.g. [7; 19], patient safety, e.g. [4; 14], quality of care, e.g. [11], the efficiency of healthcare delivery operations, e.g. [7; 13] and the cost of these operations, e.g. [1]. That being said, the majority of the reviewed studies, however, share two types of limitations: 1) they tend to study specific systems and their impacts on a particular output, and 2) most of these studies lack adopting socio-technical aspects to cover the different levels of healthcare delivery, which makes their findings questionable, especially when issues around patient outcomes and safety are of concern (ibid). Moreover, they focus narrowly on cost containment rather than how to support value-based care delivery. In addition, the current literature shows contradictory results from different studies on the impact of IS/IT on different outputs such as quality of care, patient safety, patient outcomes, cost, and efficiency [3; 9] which calls for a deeper examination of the business value of IS/IT in healthcare to investigate the impact of IS/IT on the organisational performance of healthcare providers.

Patient-centric care, an emerging key success factor for healthcare delivery, provides customised precision care to each patient's individual needs and requirements [17]. The literature identifies several components of patient-centric care delivery, including; patient participation and involvement and the context where care is delivered [12]. Hence, investigating the role of IS/IT in delivering patientcentric care is vital for today's healthcare systems and structures and to date is not well studied.

Based on the above, the primary focus of this study was to gain a more comprehensive understanding of the healthcare value creation and specifically on how 
and why point of care systems in hospitals might enable and support value generation. Hence, the main research question for this study is:

Q: How can point of care systems enable and support values-based care delivery?

The remainder of this paper is structured as follows: the following section presents a brief background on point of care solutions followed by the methodology and research design including data collection and data analysis phases, as well as describing the examined point of care system and its main elements. Section 3 presents and discusses the results, followed by a conclusion that summarises the research, its implications and limitations, and future research directions.

\section{Background}

The point of care (PoC) system is an integrated care co-ordination platform that sits at the patient bedside consisting of various modules which all work in concert to provide integrated care and support functions in an acute care context. A point of care solution is distinct from an electronic medical record as it does not support all medical and clinical input and primarily is tailored around nursing and patient care activities. Many healthcare organisations are turning to point of care solutions as they enable more tailoring and are not as expensive and disruptive as large scale EMR adoptions. As a system, PoC consists of 4 tiers as described in Table1 and Figure 1a and b.
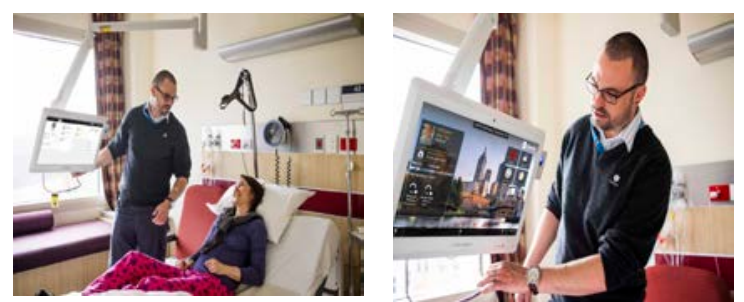

Figure 1a The PoC system

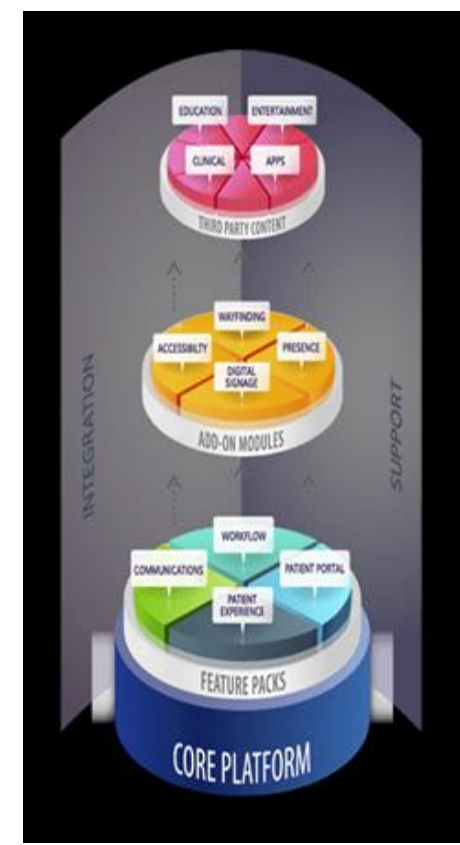

Figure $\mathbf{1 b}$ The system architecture

Table 1 The four tiers of the PoC system

\begin{tabular}{|c|c|}
\hline Tier & Description \\
\hline \multirow{7}{*}{ 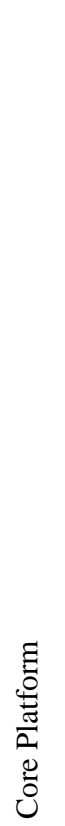 } & $\begin{array}{l}\text { This is the core foundation of all services } \\
\text { and applications that may run on top of the } \\
\text { system. The main features of this core } \\
\text { platform are: }\end{array}$ \\
\hline & 1. Centralised content management \\
\hline & $\begin{array}{l}\text { 2. Hospital systems integration through } \\
\text { HL7 to provide real-time information } \\
\text { at the point of care }\end{array}$ \\
\hline & $\begin{array}{l}\text { 3. Highly secure environment with 256- } \\
\text { bit encryption for all patients' } \\
\text { information }\end{array}$ \\
\hline & $\begin{array}{l}\text { 4. Multimedia for patients, including } \\
\text { IPTV, Internet access, and video } \\
\text { streaming on any connected terminal. }\end{array}$ \\
\hline & $\begin{array}{l}\text { 5. Customised branding to provide as } \\
\text { consistent experience as possible for } \\
\text { both patients and clinicians. }\end{array}$ \\
\hline & $\begin{array}{l}\text { 6. Proactive management for patient } \\
\text { satisfaction through real-time surveys } \\
\text { about various aspects of their care, } \\
\text { stay, or treatment. }\end{array}$ \\
\hline
\end{tabular}




\begin{tabular}{|c|c|}
\hline 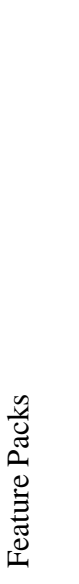 & $\begin{array}{l}\text { This tier addresses three areas: } \\
\text { 1. Enhancing patient experience through } \\
\text { personalised treatment plans, better } \\
\text { communications with their clinicians, } \\
\text { as well as providing a wide range of } \\
\text { entertainment choices. } \\
\text { 2. Improving clinical workflow by } \\
\text { assuring the access to valid } \\
\text { information and/or valid real-time } \\
\text { data. } \\
\text { 3. Engaging patients in their care plans, } \\
\text { education programs, and } \\
\text { communicating with their clinicians } \\
\text { through efficient and easy to use } \\
\text { patient portals. }\end{array}$ \\
\hline 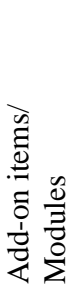 & $\begin{array}{l}\text { This tier aims to provide patients with help } \\
\text { and support for their orientation and } \\
\text { introduction to available services. This is } \\
\text { enabled through providing digital signage, } \\
\text { way finding, accessibility options (screen } \\
\text { readers, eye-tracking, speech recognition } \\
\text { and so on), and presence (Who's done } \\
\text { what). }\end{array}$ \\
\hline 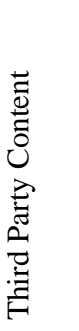 & $\begin{array}{l}\text { This tier is designed to provide third part } \\
\text { contents for both patient entertainment and } \\
\text { patient education. While the former is } \\
\text { based on personal choices, the latter is } \\
\text { based on a patient's profile, age or } \\
\text { cognitive ability. The care team can also } \\
\text { assign personalised/ customised content } \\
\text { based on their judgement/ assessment for } \\
\text { patients' individual health conditions. }\end{array}$ \\
\hline
\end{tabular}

\section{Methodology and Research Design}

This study was exploratory, as it is planned to be a broad-ranging, purposive, systematic, and prearranged undertaking designed to maximise the discovery of generalisations leading to description and understanding of the area of research in an emerging domain [18]. In order to answer the research question, the study adopted a qualitative research strategy which enabled the carrying out of deeper investigations about a diverse set of topics as is the case here [21]. To operationalise this study, a case study was deemed appropriate for this research [21]. Single case study has been extensively used in the area of health information systems to evaluate various applications, see for example [2; 8; 20]. The selected case was a multi-site, not-for-profit, tertiary, private healthcare system in Australia. Data collection and data analysis commenced only once all ethical clearances were obtained.

\section{Data Collection}

Data collection involved several approaches including site visits, attending vendor presentations, reading and analysing various secondary data sources such as reports and documents as well as conducting semi-structured interviews. This enabled a rich source of data to be collected as well as ensure triangulation and thereby a high level of rigor and data accuracy to ensue [21].

A series of 15 semi-structured interviews were conducted at the selected case. The interviews took place between December 2015 and March 2016. During the interviews, the participants were asked questions on the interaction between the system and various stakeholders, as well as any problems and issues around the system. To subscribe to recommended practices to enhance the reliability of data [5], interviews were transcribed by one researcher and checked by another. Standard qualitative techniques such as thematic analysis was employed to analyse collected data and a priori themes were developed around value, patient-centric care activities as well as clinical and patient requirements.

Of the 15 interviews, 7 interviews were conducted with staff from Clinical Services (47\%), and 2 from Food Services (13\%), 2 from Environmental Services (13\%), and 4 interviews with one IT staff (27\%) as Figure 2 depicts.

On answering the question on how long they had been working for the selected case, the mean of years of work for the hospital was 5.875 years with a standard deviation of 3.4. It was notable that the years of work for the interviewees from Clinical Services were shorter (4.214) with a standards deviation of 3.47 .

On answering the question on how comfortable the interviewees were with using IT, the majority of the interviewees stated they were fairly comfortable to very comfortable, with only one interviewee from Food Services was not comfortable.

\section{The Point of Care System}

The studied point of care system (POC) is an integrated solution at the bedside that serves to address the multiple information needs for patients, clinicians, nurses, and other services such as environmental services, logistic services, food services etc. This system has been up and running in different prestigious hospitals in some developed countries. However, the selected case is one of the first hospitals to implement this system in the Australian context; and thus, an exemplar case study. 


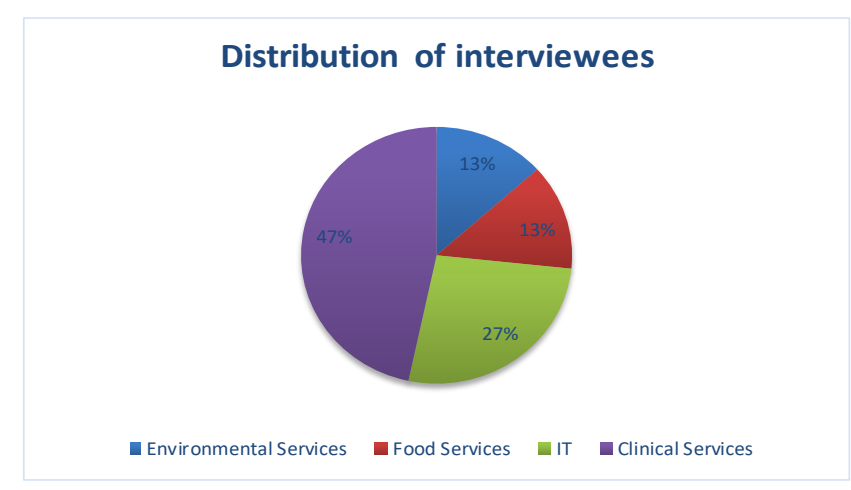

Figure 2: The distribution of the interviewees

In addition to these four tiers, the system integrates another component of external services such as the patient's meal ordering systems, environmental services, nurse calling, buildings and assets services, and patient transportation systems. The two major additions to the system at the selected case included a) designing a meal ordering module for patients and b) designing a dedicated module for the Environmental Services team make wards ready on time for the next occupancy.

\section{Results and Discussion}

The system is not a comprehensive medical records system, rather it is a clinical system at the bedside that aims to allow more interaction between patients and their clinicians as described by this interviewee:

"It [The system] is not a true clinical IT repository. It's not an electronic medical record or anything like that, but it's putting things at the bedside that staff need to use to be able to make decisions quickly, or to be able to engage a patient". [IT03\#1]

The system also has the potential to be a decision support system:

"It [The system] is sort of a decision support systems. As we put more applications on it, we'll get there”. [IT02\#1]

That being said, the system appears to have had positive impacts on various aspects of care delivery. A senior executive referred to the system as a major enabler to higher levels of occupancy:

"I think the systems that we've got here, particularly around point-of-care, has enabled us to go from zero occupancy to virtually 100\%." [Ехес\#01-1].

Implementing the system also created a change into the process of delivering care. Nurses now are required to go to ward on an hourly basis to check their patients' needs and report that onto the point of care system. As a result of this, enabling the move from provider-centric to patient-centric healthcare system was also another benefit of implementing this system and using it according to a series of interviewees:

"..., the point-of-care system is about creating an environment of patient-centric care, putting the staff and the doctors back where they want to be, which is in the patient's room." [Exec\#01-2].

"Let's not go and find a computer at the desk; let's use the computer in the room and engage the patients about their results. Because, without the patient in the bed, there's no results. I philosophically don't believe you should do that separate to the patient, which is why we can look up radiology and pathology at the bedside. Which is why we have conversations every hour around pain, around injuries, around managing risk and all that kind of stuff. That's why we have education on that system as well, the medication chart and all the other things that we're putting in that I've talked to you about. Putting stuff back where they need to be." [NUM\#01-2].

Upon checking the clinical dashboard at the selected case, we found that the major incidents were notably decreasing since the introduction of the system. Asking about how the system reduced falls, major incidents, medication errors and other indicators, a number of interviewees referred to the newly introduced hourly rounding as a contributor:

"Yeah, because it's an enabler for all of that to happen. If staff are not in the patient's room, that's when bad things happen. That's when patients feel dissatisfied, that's when the doctor doesn't know what's going on, etc. If you can use it as an enabler to have information at the bedside, to have staff at the bedside, then you can do what you need to do, which is develop a relationship with the patient, care for them, manage their risk, manage their length of stay and outcomes, etc". [NUM\#03-1].

The system also enabled creating a new collaborative culture between patients and their clinicians according to this interviewee:

"Yeah. It helps create the right culture as well. Culture is the most important thing in healthcare, because how you behave as a clinician and how you develop relationship with a patient - so your culture is what drives your results as well." [NUM\#02-1]

As discussed in the previous section, the system has had another two major additions to it at the selected case; one is designed for meal ordering by patients and the other is dedicated for the Environmental Services team to make wards ready on time for the next occupancy as the following subsections will show. 


\subsection{Food Services}

Prior to the current point of care system, the processes in the Food Services were facilitated using an application that will be named Food Order for the purpose of this paper. This application had been in use since the opening of the hospital and has partially been replaced by the current point of care system.

Managing patients' meal orders is handled by the Department of Food Services. The contact point is the Menu Monitors, who take the meal orders a day ahead. Prior to the current system, this was facilitated by Food Order. Hardware speaking, Food Order was installed on a number of computers on wheels (mainly laptops). Taking orders from patients includes discussing the options and personal preferences for the breakfast, lunch, and dinner for the next day. This process will take up to $70 \%$ of the work time for the Menu Monitors, with a rate of minimum 14 patients to be seen per hour. That is 3-4 minute per patient. Patients can choose three full courses for the next day from a menu that changes every three years hospital wide. These data are then entered by the Menu Monitors into Food Order, and then spread sheets are printed off this system. These sheets are then assigned to different chefs as 'Production Lists'. Throughout the day, three production lists are prepared, one in the morning (7:00 am), the second is after breakfast (10:00 $\mathrm{am})$, and the third is at 3:30 PM for the evening. Two main issues were found in this way of handling patients' meals. The first relates to the data collected, and the second is about Food Order performance and functionality.

Although preparing the production lists is time consuming and requires lots on interaction between patients and their Menu Monitors, there existed four types of data were not possible to capture using Food Order and the process around it. Those are:

1. Late orders: Meal orders for patients admitted after 8 pm during week days and after 7 pm during weekends were not attended to. This group of patients will not have the choice of food in their first stay day as they are not seen by the Menu Monitors. Rather, they will have the default meal for that day.

2. Food allergy for visited patients: Food Order does not have the capability to record any food allergy patients may have. This piece of information normally comes from patient information system (PIS). In many cases this information are then not passed on to the chefs, so they make meals without taking that into consideration.

3. Discharged people: Depending on the time patients are discharged, many cases reportedly happened where meal orders were made, but patients had been discharged. Again, this piece is coming from
PIS, and not passed on to the Food Services staff at the right time.

4. People with changed diet codes: As treatment plans progress, patients may change their diet codes, such as changing from 'not eating' to 'eating' and from 'soft' to 'hard' food. These changes were also managed by nurses using PIS, however, the cooperation between nurses and Food Services was not maintained at all times, which resulted in many cases meals were not made according to these changes.

These issues have direct and indirect impacts on the cost and quality of provided services as Table 2 summarizes.

Table 2 Issues with meal orders pre Point of Care

\begin{tabular}{|l|l|l|}
\hline Issue & $\begin{array}{l}\text { Impact on } \\
\text { Cost }\end{array}$ & $\begin{array}{l}\text { Impact on } \\
\text { quality }\end{array}$ \\
\hline $\begin{array}{l}\text { Late } \\
\text { orders }\end{array}$ & $\begin{array}{l}\text { None, as patients } \\
\text { receive the default } \\
\text { meal for the next } \\
\text { day }\end{array}$ & $\begin{array}{l}\text { Negative } \\
\text { impact on } \\
\text { patient } \\
\text { satisfaction }\end{array}$ \\
\hline $\begin{array}{l}\text { Food } \\
\text { allergy for } \\
\text { visited } \\
\text { patients }\end{array}$ & $\begin{array}{l}\text { Wasted food, } \\
\text { unplanned care for } \\
\text { the resulting } \\
\text { allergy which may } \\
\text { result in } \\
\text { implications on } \\
\text { patients' insurance } \\
\text { cover }\end{array}$ & $\begin{array}{l}\text { Negative } \\
\text { impact on } \\
\text { patient } \\
\text { satisfaction and } \\
\text { safety as well } \\
\text { as trust in the } \\
\text { hospital }\end{array}$ \\
\cline { 1 - 1 } $\begin{array}{l}\text { Discharge } \\
\text { d people }\end{array}$ & Wasted food & $\begin{array}{l}\text { More pressure } \\
\text { on chefs }\end{array}$ \\
\cline { 1 - 1 } $\begin{array}{l}\text { People } \\
\text { with } \\
\text { changed } \\
\text { diet codes }\end{array}$ & & $\begin{array}{l}\text { Negative } \\
\text { impact on } \\
\text { patient } \\
\text { satisfaction }\end{array}$ \\
\hline
\end{tabular}

Using the point of care system, patients can place their orders of meals through their user interface. The arrival of this function to the point of care system has partially solved the issues faced by the conventional system; namely late patients (after 8 pm weekdays and after 7:00 pm weekends), allergy data, and patients with changed diet codes. Late patients can order their favourite meals for the next day if they want to, they can state their allergy status through the admission form, and nurses can change patients' diet codes right from the point of care system.

Currently, no more than $10 \%$ of the patients are using the point of care system to order their meals. On asking on the reasons behind that, two main reasons were identified. The first is some issues with the user interface, especially with elderly patients, as patients need to scroll down to the bottom of the screen to reach the meal ordering function. During the scrolling down, 
a number of pop-ups will appear and may disrupt their endeavour:

"We go up and introduce the system to them. When you go into the system at the minute, the way they implemented it, it is hard to use. You've got to scroll down to find the ordering" [FSA_1].

The other reason relates to the conceptual resistance by some patients to rely on a 'machine' to order their meals, preferring human-human interaction more than human-machine interaction. This was agreed upon by both interviewees from the Food Services.

As a result of being in a hybrid environment, i.e. the minority of patients are using the point of care system to order their meals, and the majority are still using the conventional way to order their meals, Food Order now has coloured dots to indicate the patients who used the point of care system to order their meals. Hence, the Menu Monitors do not need to visit them to organise their meals.

With the expected increase of the uptake of this function in the point of care system, more patients will adopt this function, and more time required to see patients by their Menu Monitors will be freed-up. This is expected to have positive impacts on the hospital and its patients. environmental services

The Environmental Services is a dedicated team whose two main responsibilities are 1) providing all types of cleaning (steam cleaning, buffer cleaning, advanced cleaning, curtains cleaning, etc.), and 2) patient transportation. In terms on human resources, the Environmental Services team comprises about 60 staff members. Of this figure, about 40 works in cleaning, and the reminder works in patient transportation.

\subsection{Environmental Services}

Unlike the Food Services, which had Food Order as a computerised system to facilitate food-related processes prior to the point of care system, the operations of the Environmental Services were mainly based on phone to phone and face to face communications. Introducing the point of care system and integrating the Room2Go module into it has made considerable change in the processes of this vital department. The following is a summary of the process map of the Environmental Services before and after the point of care system.

The process of performing jobs by the Environmental Services before the PoC had three main steps. 1) Initiating the job by nurses and specific cleaners; 2) receiving job orders by the supervisors within the Environmental Services; and 3) assigning tasks to cleaners as Figure 2 depicts.
Nurses normally initiate job orders when needed. This includes preparing rooms before admitting new patients to these rooms, cleaning rooms after patients have been discharged, and as needed if a patient had an incident such as bleeding or vomiting. These job orders go to the supervisors from the Environmental Services using face to face or phone to phone communications tools. The supervisors in turn convey these orders to the cleaners across the hospitals using same communication means, i.e. phone and face to face. Apart from nurses, buffer cleaners and permanent cleaners can initiate job orders if need be. This normally happens when one of these cleaners realises, while doing their jobs, there exist some curtains or carpet need to be cleaned, and they do not have the required equipment to do so. Once the need of a cleaner has been established, the path of this order in dependent upon its urgency. If the job was of a higher urgency, then these cleaners inform their supervisors either by phone calls or by hand-written notes. Then the supervisors assign the tasks to different cleaners on floor accordingly. If the job was not considered urgent by these cleaners, then they will wait till the next shift of cleaners has come to do the job based on hand written notes, which caused extended times to do specific jobs. The level of urgency was left to the cleaners to decide.

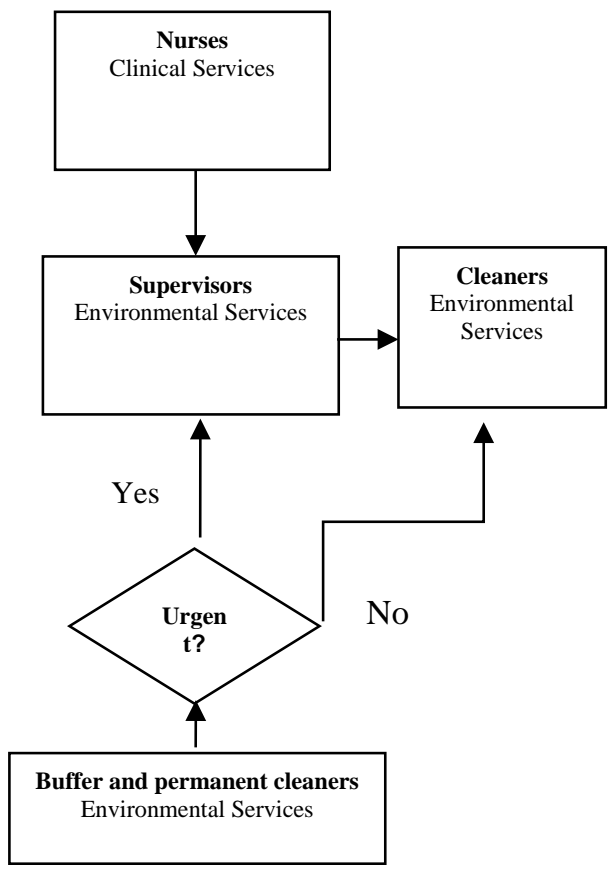

Figure 3. A map for the Environmental Services before PoC

This system had caused many problems, which can be summarised as follows: 
Over relaying on human factors: As can be seen, the whole processes of the Environmental Services team are centred on human communications and judgment. This resulted in many cases where jobs were not done or took longer time to be addressed. This is particularly acute in the cases where patients had to wait outside their rooms while cleaning the room, which resulted in unsatisfied patients and nurses.

Lack of co-ordination in the multi levels of communications: Given that nurses, supervisors, and permanent and buffer cleaners could initiate job orders, cleaners in many cases were confused about their tasks and what tasks had higher priorities. This lack of coordination was due to adopting phone calls, hand-written notes, and face to face means.

Inability to address language barriers: Given that a considerable portion of the cleaners had language barriers, their understanding of their assigned tasks over the phone or hand-written notes was reportedly limited in many cases, which caused many jobs not done properly.

More effort by cleaners: As the job orders did not have enough information about their jobs (locations, level of urgency, and required equipment), the cleaners had to go to the site to manually collect all of this information and come back to their workplace to collect the right equipment for that specific job. This caused them to walk back and forth many times, which reduced their productivity and the quality of their jobs and increased their fatigue.

Lack of accountability: As the majority of the needed jobs were verbally conveyed from one stakeholder to another, the possibility of creating accountability and tracking the performance of different units and individuals were almost impossible. This is especially acute in the case of cleaners with limited literacy, as well as the communications between nurses (Clinical Services) and the cleaners and their supervisors as Figure 2 depicts. Table 3 summaries these issues and their impacts on both cost and quality.

Table 3 Environmental services pre PoC system

\begin{tabular}{|l|l|}
\hline Problems & Impact on Cost/Quality \\
\hline $\begin{array}{l}\text { Over relaying } \\
\text { on human } \\
\text { factors }\end{array}$ & \multirow{2}{*}{$\begin{array}{l}\text { Double work resulted in many cases, } \\
\text { which implied extra cost and less quality }\end{array}$} \\
\cline { 1 - 1 } $\begin{array}{l}\text { Lack of co- } \\
\text { ordination: }\end{array}$ & \\
\cline { 1 - 1 } $\begin{array}{l}\text { Multi levels of } \\
\text { communications }\end{array}$ & \\
\hline
\end{tabular}

\begin{tabular}{|l|l|l|}
\hline $\begin{array}{l}\text { Language } \\
\text { barriers }\end{array}$ & \multicolumn{2}{|l|}{$\begin{array}{l}\text { As many jobs needed to be repeated, } \\
\text { double works resulted in many cases, } \\
\text { which implied extra cost and less quality }\end{array}$} \\
\hline & $\begin{array}{l}\text { Given the } \\
\text { missing } \\
\text { information } \\
\text { on the nature } \\
\text { of their tasks, } \\
\text { cleaners had } \\
\text { to survey the } \\
\text { location of } \\
\text { their jobs in } \\
\text { person, which } \\
\text { resulted in } \\
\text { them walking } \\
\text { cleaners } \\
\text { times/ended } \\
\text { distances. }\end{array}$ & $\begin{array}{l}\text { Due to the unneeded } \\
\text { increased workload, } \\
\text { the quality of cleaning } \\
\text { services was } \\
\text { negatively affected }\end{array}$ \\
\hline $\begin{array}{l}\text { Lack of } \\
\text { accountability }\end{array}$ & $\begin{array}{l}\text { Tracking the performance of individuals } \\
\text { and different unit was almost impossible }\end{array}$ \\
\hline
\end{tabular}

Introducing the point of care system, particularly the Room2Go, has notably streamlined the cleaning related processes of the Environmental Services, while the other vital role of the Environmental Services; namely patient transportation, is still conducted using the conventional way, with a vision to integrate this function into the point of care in later enhancements.

The Room2Go enables nurses, permanent cleaners, and buffer cleaners to log into the system and place cleaning orders with enough details about the job, its location, requirements and level of urgency. This information is then conveyed to the cleaners on floor as short text messages on their point of care phones. Based on the nature of the jobs, cleaners can choose the jobs of higher urgency, closer to their geographic location, and/ or achievable using their current equipment. This has resulted in saving cleaners' times and efforts, which in turn has shown faster responses to the cleaning needs initiated by different wards, units, and individuals.

According to the interviewees, not only has the Room2Go enhanced quality and productively of cleaners, but it has also resulted in a simpler map of cleaning processes performed by the Environmental Services as Figure 4 depicts. 


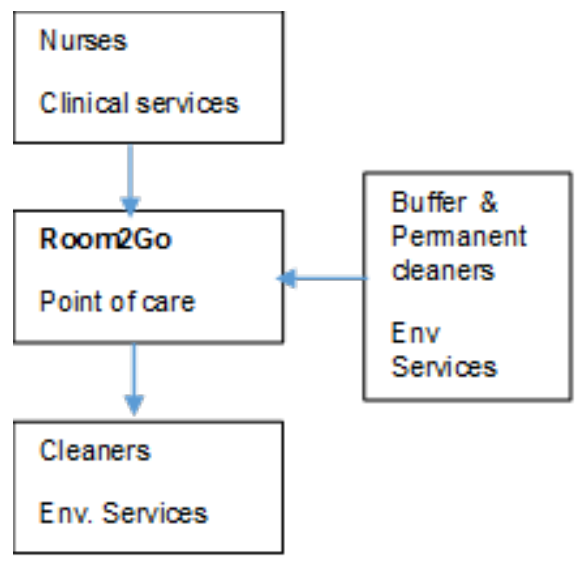

Figure 4 Environmental Services with PoC

The initial findings from the interviews show that the use of the point of care system to support the cleaning processes at the selected hospital has addressed most of the problems faced by the conventional way to manage the cleaning needs for the hospital. Table 4 summarises these findings.

Table 4 The impact of Room2Go

\begin{tabular}{|c|c|c|}
\hline Problems & $\begin{array}{l}\text { How has the } \\
\text { point of care } \\
\text { addressed the } \\
\text { problems }\end{array}$ & $\begin{array}{l}\text { Impact on } \\
\text { Cost/Quality }\end{array}$ \\
\hline $\begin{array}{l}\text { Over } \\
\text { relaying on } \\
\text { Human } \\
\text { Factors }\end{array}$ & $\begin{array}{l}\text { This problem } \\
\text { has been } \\
\text { partially solved, } \\
\text { as human still } \\
\text { need to log in } \\
\text { and place job } \\
\text { orders. The } \\
\text { existence of } \\
\text { Room2Go } \\
\text { though has } \\
\text { increased the } \\
\text { ability to place } \\
\text { jobs and track } \\
\text { them. }\end{array}$ & $\begin{array}{l}\text { Positive } \\
\text { M }\end{array}$ \\
\hline $\begin{array}{l}\text { Lack of Co- } \\
\text { ordination }\end{array}$ & \multirow{2}{*}{$\begin{array}{l}\text { The } \\
\text { introduction on } \\
\text { Room2Go has } \\
\text { eliminated one } \\
\text { layer of } \\
\text { communications } \\
\text { in the process } \\
\text { map of cleaning } \\
\text { services. That is } \\
\text { the supervisors, } \\
\text { which has freed } \\
\text { up their time, } \\
\text { and has rebuilt }\end{array}$} & \multirow[t]{2}{*}{$\begin{array}{l}\text { Positive } \\
\text { M }\end{array}$} \\
\hline $\begin{array}{l}\text { Multi levels } \\
\text { of } \\
\text { communica } \\
\text { tions }\end{array}$ & & \\
\hline
\end{tabular}

\begin{tabular}{|c|c|c|}
\hline & $\begin{array}{l}\text { their roles } \\
\text { around } \\
\text { coordinating } \\
\text { different tasks } \\
\text { and following } \\
\text { up with } \\
\text { different } \\
\text { stakeholders. }\end{array}$ & \\
\hline $\begin{array}{l}\text { Language } \\
\text { barriers }\end{array}$ & $\begin{array}{l}\text { As job orders } \\
\text { come to } \\
\text { cleaners in a } \\
\text { form of short } \\
\text { text messages } \\
\text { on their point of } \\
\text { care phones, } \\
\text { this problem has } \\
\text { been partially } \\
\text { solved. }\end{array}$ & $\begin{array}{l}\text { Positive } \\
\text { L }\end{array}$ \\
\hline $\begin{array}{l}\text { More effort } \\
\text { by cleaners }\end{array}$ & $\begin{array}{l}\text { As the jobs } \\
\text { orders come } \\
\text { with a relatively } \\
\text { comprehensive } \\
\text { set of } \\
\text { information, } \\
\text { cleaners don't } \\
\text { need to go and } \\
\text { assess the job } \\
\text { before actually } \\
\text { doing the job, } \\
\text { which resulted } \\
\text { less effort from } \\
\text { them, and more } \\
\text { tasks performed } \\
\text { every day than } \\
\text { before }\end{array}$ & $\begin{array}{l}\text { Positive } \\
\text { M }\end{array}$ \\
\hline $\begin{array}{l}\text { Lack of } \\
\text { accountabil } \\
\text { ity }\end{array}$ & $\begin{array}{l}\text { All jobs' orders } \\
\text { are now } \\
\text { documented and } \\
\text { stored in the } \\
\text { system. Hence, } \\
\text { tracking } \\
\text { different jobs } \\
\text { and their } \\
\text { progress and the } \\
\text { responses from } \\
\text { different } \\
\text { stakeholders is } \\
\text { always possible. }\end{array}$ & $\begin{array}{l}\text { Positive } \\
\mathrm{H}\end{array}$ \\
\hline
\end{tabular}

Legend: L: Low, M: Medium, H: High

\section{Conclusion}

This study contributes to the effort of shaping patient-centric care delivery systems by investigating the business value of point of care system by examining its ability to deliver high value patientcentric care across a private not-for-profit tertiary 
healthcare group in Australia. In addition, the study investigates the role of this system in streamlining various supporting services around providing care such as environmental and food services. The results from this first stage of this qualitative study show that the examined point of care system supports patientcentric care by facilitating the fostering of good relationships between patients and their clinicians, as well as building a cultural shift towards patient-centric care as part of standard practice.

From a clinical perspective, the examined point of care system was found to clearly support the sustained delivery of patient-centric care. Critical aspects were enabled and supported through the system including patient participation and involvement, the relationship between the patient and the healthcare professional and the sharing of pertinent information. All of these aspects have contributed to a higher level of satisfaction of patients. More importantly, the introduction of the system has reduced the number and severity of major incidents due to clinicians are more frequently at the bedside that before introducing the system as the Results section showed.

From a non-clinical perspective, this system also seems to provide tangible benefits in streamlining the workflow around various tasks in supporting services such as environmental and food services. The introduction of the added modules for ordering food and facilitating environmental services to the point of care system demonstrated some direct benefits in streamlining daily tasks around these two areas, which also resulted in higher productivity and satisfaction by the staff members and also better satisfaction by the patients.

In addition, a culture shift took place at patients', clinicians', and staff members' sides. This cultural shift is about creating more collaborations between patients and their clinicians, and also creating higher levels of accountability at the staff members' side. Thus, the study has far reaching implications as it highlights key aspects of enabling and supporting patient-centric care through technology implementation and adoption. It also presents lessons on the value of point of care systems for healthcare providers and highlights some points that decision makers may find useful to make informed decisions about investing in this area.

The study also has implications for theory, most especially with regard to trying to define key contributors to realising high value healthcare delivery. As noted by many scholars such as [15], value-based care delivery is essential for today's healthcare environment but how to deliver valuebased care needs to be better understood [6]. In particular, it is necessary to clearly identify key drivers as well as barriers and facilitators. This study is a first step to developing such a better understanding as well as understanding the core enabling role for technology.

This study has a number of limitations. Firstly, the point of care system was recently introduced, some of its functions were being added on a monthly basis. Hence, a number of the interviewees reported that they were not using the system at its maximum capacity. This also caused that the quality indicators were limited and did not enable extracting clear trends and patterns around the safety and quality of care (falls, pressure injuries/ulcers, medication errors, etc.) and patient satisfaction (pain control, complains, compliments, etc.). Secondly, the study is mainly qualitative and used interviews, site visits, and archival documents and reports. Quantifying the business value of this system is possible subject to having access to datasets that cover longer periods of leveraging the point of care system. Hence, this is a future research direction of this study.

\section{Acknowledgements}

The support and assistance from Ms Lou O'Connor is greatly appreciated. In addition, the work of the research assistant Imran Muhammad is acknowledged and thank you to all participants for giving your time so generously.

\section{References}

[1] Balabanova, D., Mills, A., Conteh, L., Akkazieva, B., Banteyerga, H., Dash, U., . . . Islam, Z. (2013). Good Health at Low Cost 25 years on: lessons for the future of health systems strengthening. The Lancet, 381(9883), 2118-2133.

[2] Baskerville, R. L., \& Wood-Harper, A. T. (2016). A critical perspective on action research as a method for information systems research Enacting Research Methods in Information Systems: Volume 2 (pp. 169-190): Springer.

[3] Chaudhry, B., Wang, J., Wu, S., Maglione, M., Mojica, W., Roth, E., . . Shekelle, P. G. (2006). Systematic Review: Impact of Health Information Technology on Quality, Efficiency, and Costs of Medical Care. Annals of Internal Medicine, 144(10), 742-752. doi: 10.7326/0003-4819-14410-200605160-00125

[4] Farley, H. L., Baumlin, K. M., Hamedani, A. G., Cheung, D. S., Edwards, M. R., Fuller, D. C., . . . McClay, J. C. (2013). Quality and safety implications of emergency department information systems. Annals of emergency medicine, 62(4), 399-407.

[5] Flick, U. (2009). An introduction to qualitative research. London: Sage. 
[6] Gibbings, R., Schaffer, J., and Wickramasinghe, N. 2017. Using Health Information Technology to En-hance Care Outcome Accountability through Bundled Payments Poster Presented at Epworth Research Week 2017. Poster 13

[7] Goldzweig, C. L., Orshansky, G., Paige, N. M., Towfigh, A. A., Haggstrom, D. A., Miake-Lye, I., . . . Shekelle, P. G. (2013). Electronic patient portals: evidence on health outcomes, satisfaction, efficiency, and attitudes: a systematic review. Annals of Internal Medicine, 159(10), 677-687.

[8] Jones, K. H., Ford, D. V., Jones, C., Dsilva, R., Thompson, S., Brooks, C. J., . . Lyons, R. A. (2014). A case study of the Secure Anonymous Information Linkage (SAIL) Gateway: a privacy-protecting remote access system for health-related research and evaluation. Journal of Biomedical Informatics, 50, 196-204.

[9] Jones, S. S., Rudin, R. S., Perry, T., \& Shekelle, P. G. (2014). Health Information Technology: An Updated Systematic Review With a Focus on Meaningful Use. Annals of Internal Medicine, 160(1), 48-54. doi: 10.7326/M13-1531

[10] Karpathiou, V., \& Wickramasinghe, N. (2016). Generating healthcare value with technology: digital divide or digital panacea?

[11] Kellermann, A. L., \& Jones, S. S. (2013). What it will take to achieve the as-yet-unfulfilled promises of health information technology. Health Affairs, 32(1), 63-68.

[12] Kitson, A., Marshall, A., Bassett, K., \& Zeitz, K. (2013). What are the core elements of patient-centred care? A narrative review and synthesis of the literature from health policy, medicine and nursing. Journal of advanced nursing, 69(1), 4-15.

[13] Lee, T.-F. (2013). An efficient chaotic maps-based authentication and key agreement scheme using smartcards for telecare medicine information systems. Journal of medical systems, 37(6), 1-9.

[14] Middleton, B., Bloomrosen, M., Dente, M. A., Hashmat, B., Koppel, R., Overhage, J. M., . . . Zhang, J. (2013). Enhancing patient safety and quality of care by improving the usability of electronic health record systems: recommendations from AMIA. Journal of the American Medical Informatics Association, 20(e1), e2-e8.

[15] Porter, M. (2010). What Is Value in Health Care? The New England journal of medicine, 364(13). doi: 10.1056/NEJMc1101108

[16] Porter, M. E., \& Teisberg, E. O. (2006). Redefining health care : creating value-based competition on results. Boston, Mass.: Harvard Business School Press.
[17] Reynolds, A. (2009). Patient-centered care. Radiologic Technology, 81(2), 133-147.

[18] Stebbins, R. A. (2001). Exploratory research in the social sciences (Vol. 48): Sage.

[19] Tucker, C. A., Cieza, A., Riley, A. W., Stucki, G., Lai, J. S., Ustun, T. B., . . Forrest, C. B. (2014). Concept analysis of the Patient reported outcomes measurement information system (PROMIS ${ }^{\circledR}$ ) and the international classification of functioning, disability and health (ICF). Quality of Life Research, 23(6), 1677-1686.

[20] Wickramasinghe, N., Vaughan, S., Haddad, P., Han Lin, C., Moghimi, H., \& Delimitros, H. (2015). Identifying key success factors for the adoption and implementation of a chemotherapy ordering system: A case study from the Australian private healthcare sector. Paper presented at the AMCIS 2015 August 13-15, 2015 Proceedings. ISBN: 9780-9966831-0-4., Puerto Rico.

[21] Yin, R. K. (2014). Case study research: design and methods (Fifth edition. ed.): SAGE. 